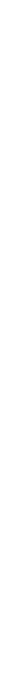

\title{
Erich Kästner in Romanian III.
}

\begin{tabular}{|c|c|}
\hline Authors: & Dragoş Carasevici \\
\hline Submitted: & 21. October 2019 \\
\hline Published: & 22. October 2019 \\
\hline Volume: & 6 \\
\hline Issue: & 10 \\
\hline Affiliation: & $\begin{array}{l}\text { German Studies Department of the „Alexandru loan Cuza” } \\
\text { University from Laşi, Romania. }\end{array}$ \\
\hline Languages: & Romanian, Moldavian, Moldovan \\
\hline Keyword & Translations, Poems, Erich Kaestner, German, Romanian. \\
\hline ategorie & DEMETRIOS Literary Works \\
\hline & 10.17160/josha.6.10.607 \\
\hline
\end{tabular}

Abstract:

This article represents the small line of translation of poems by the wonderful German writer, publicist, screenwriter, and cabaret poet, Erich Kästner. The translation of this collection of poems will be carried out thanks to the work of one of our editor Dr. Dragos Caracevici from German into Romanian. The third poem is entitled "Sachliche Romanze " and can be heard in German by following the link from the website "GESPROCHENE DEUTSCHE LYRIK". Dragoş is Lecturer at the German Studies Department of the „Alexandru loan Cuza” University from laşi, Romania, and Ph.D. of the same university and of Université de Genève, Switzerland, with a thesis on Friedrich Dürrenmatt's adaptations and stagings (2011). He works in the field of German and Swiss Studies as well as in the field of literary translations and Theatre Studies. $\mathrm{He}$ is also one of the editors of "Acta lassyensia Comparationis", a Romania-based international journal for Comparative Literature. The picture on the cover: OMuenchen-Lese | Erich Kästner

\section{JOSHA Joumua os simmea Humanities and Arts}


Journal of Science,

Humanities and Arts

\section{Erich Kästner auf Rumänisch übersetzt III}

\section{übersetzt von}

Dragoş Carasevici

This article represents the small line of translation of poems by the wonderful German writer, publicist, screenwriter, and cabaret poet, Erich Kästner.

The translation of this collection of poems will be carried out thanks to the work of one of our editor Dr. Dragos Caracevici from German into Romanian.

The third poem is entitled, Sachliche Romanze" and can be geard by following the lick to the Website of

\section{“GESPROCHENE DEUTSCHE LYRIK”.}

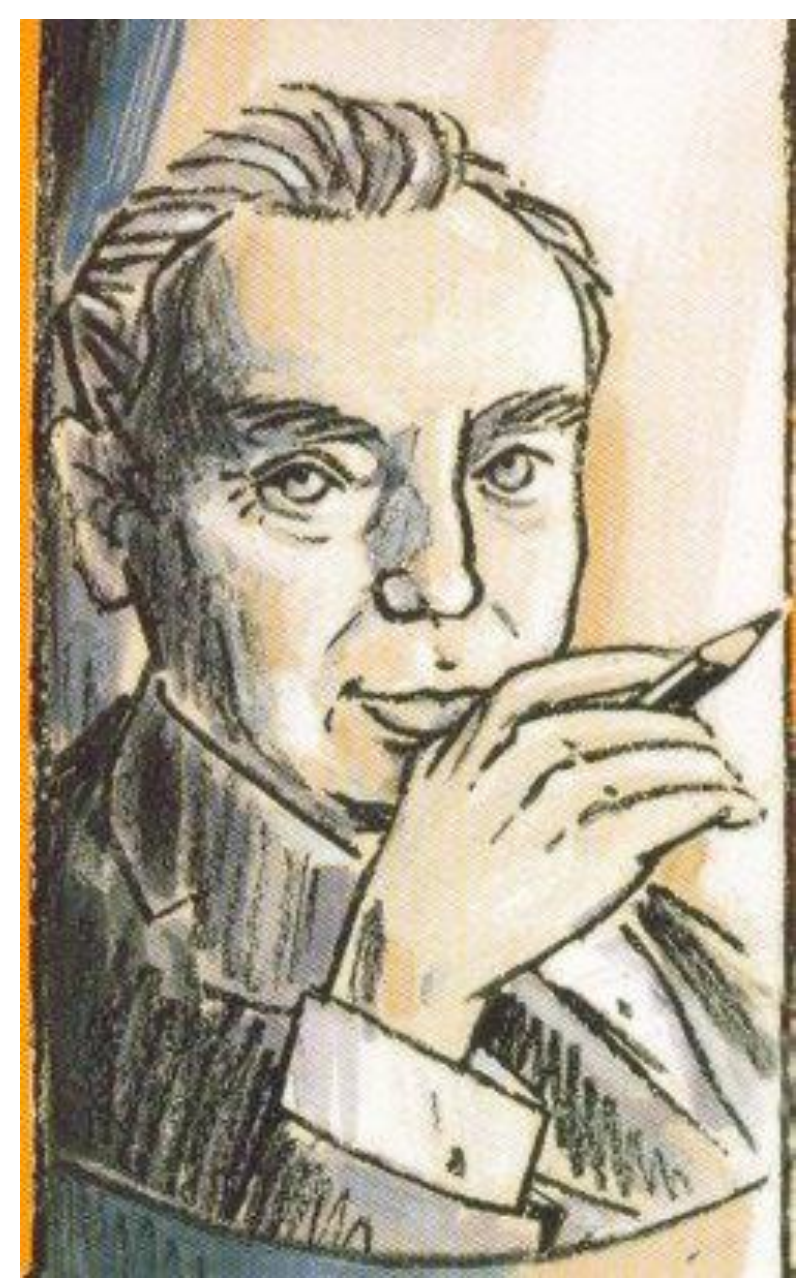

C Muenchen-Lese | Erich Kästner 


\section{Sachliche Romanze}

Als sie einander acht Jahre kannten (und man darf sagen: sie kannten sich gut),

kam ihre Liebe plötzlich abhanden. Wie andern Leuten ein Stock oder Hut.

Sie waren traurig, betrugen sich heiter, versuchten Küsse, als ob nichts sei, und sahen sich an und wußten nicht weiter.

Da weinte sie schließlich. Und er stand dabei.

Vom Fenster aus konnte man

Schiffen winken.

Er sagte, es wäre schon Viertel nach Vier

und Zeit, irgendwo Kaffee zu trinken.

Nebenan übte ein Mensch Klavier.

Sie gingen ins kleinste Cafe am Ort und rührten in ihren Tassen.

Am Abend saßen sie immer noch dort.

Sie saßen allein, und sie sprachen kein Wort

und konnten es einfach nicht fassen.

\section{Romantă obiectivă}

Acum opt ani ei doi s-au cunoscut (si trebuie spus: s-au cunoscut chiar bine),

când brusc iubirea lor se transformă$\mathrm{n}$ rebut, asa cum altora jobenul nu le mai convine.

Tristi se-amăgeau cu sărutări stâlcite si pretindeau că totul e perfect si se priveau apoi cu fetele uimite. Curând ea plânse. Iar el rămase drept.

Fereastra lor dădea direct spre mare. El spuse că e patru si un sfert si c-ar fi timpul pentru o plimbare. Alături un pian valsa incert.

Se asezară pe-o terasă nu departe si-amestecară-n cesti cafeaua slabă. Sezură singuri până târziu în noapte. Stăteau tăcuti, priveau în altă parte si nu puteau nicicum să înteleagă. 